\title{
Model Quadruple Helix dalam Pemberdayaan Perekonomian Lokal Berbasis Desa Wisata di Desa Duren Sari Kabupaten Trenggalek
}

\author{
Ajie Hanif Muzaqi*, Fauziah Hanum \\ Program, Studi Administrasi Publik, Fakultas Ilmu Sosial dan Ilmu Politik, \\ Universitas Kadiri, Jawa Timur, Indonesia \\ *Email Korespondensi : ajiehanif@unik.ac.id
}

\begin{abstract}
ABSTRAK
Pariwisata di Indonesia beberapa tahun kebelakang berkembang sangat pesat karena sektor pariwisata dapat menjamin kemajuan suatu wilayah dan menciptakan kesejahteraan masyarakat yang lebih merata. Kabupaten Trenggalek adalah salah satu Kabupaten di Indonesia yang memiliki potensi besar pada sektor pariwisata dan salah satu Desa yang sangat berpotensi menjadi Desa Wisata adalah Desa Duren Sari. Namun pada kenyataanya kesejahteraan masyarakat sekitar desa ini masih belum merata dan hanya berfokus pada pembangunan di sektor pertanian. Oleh sebab itu, sektor pariwisata di desa ini perlu untuk dikembangkan. Model Quadruple Helix sangat ideal dalam mengembangkan wisata karena melibatkan kolaborasi aktor (pemerintah, masyarakat, intelektual akademisi, dan bisnis). Penelitian ini bertujuan untuk mengetahui implementasi quadruple helix dalam pemberdayaan perekonomian lokal. Selain itu, penelitian ini juga bertujuan untuk menemukan model interaksi setiap aktor helix dalam pemberdayaan perekonomian lokal. Jenis penelitian yang digunakan adalah penelitian kualitatif. Hasil penelitian adalah keterlibatan aktor quadruple helix dapat menjadi solusi pemberdayaan ekonomi lokal di Desa Duren Sari karena kolaborasi yang dijalankan memfokuskan pada tujuan bersama. Model interaksi antar aktor helix menciptakan inovasi dan kreativitas baru dimana hal tersebut dapat disajikan dalam bentuk kebijakan dan program pembangunan daerah.
\end{abstract}

Kata Kunci: Quadruple Helix; Pemberdayaan; Perekonomian Lokal

\section{PENDAHULUAN}

Pembangunan daerah adalah bagian dari agenda pembangunan nasional dan tidak terlepas dari konsep otonomi daerah. Wujud dari agenda pembangunan dalam konsep otonomi daerah tersebut perlu mendapat perhatian dan tanggung jawab dari tiap-tiap daerah otonom serta didukung oleh kewenangan yang seluas luasnya. Hal tersebut tertuang dalam amanat Undang-Undang Nomor 32 Tahun 2004 tentang Pemerintahan daerah dimana kebijakan yang lahir dari Pemerintah Daerah bertujuan untuk menjawab tuntuan perubahan dan reformasi tentang penerapan nilai-nilai demokrasi antara pusat dan daerah yang diharapkan berdampak pada pemberdayaan masyarakat lokal (Firmanto, 2019). Seperti yang kita ketahui bahwa Bangsa Indonesia merupakan bagian dari negara berkembang namun memiliki potensi pariwisata yang besar. Potensi pariwisata yang dimiliki tanah air ini lebih didominasi oleh wisata alam seperti laut, gunung, dan pulau yang sangat eksotis. Selain itu, Bangsa Indonesia juga memiliki kekayaan flora dan fauna yang jumlahnya 
berlimpah. Kondisi ini tercipta berkat letak geografis Bangsa Indonesia sebagai negara tropis dan dilalui garis khatulistiwa.

Selain itu, Bangsa Indonesia yang berbentuk negara kepulauan menghasilkan masyarakat yang multikultural dan majemuk. Kemajemukan masyarakat Bangsa Indonesia ini dapat menjadi ciri khas yang tidak akan dijumpai di bangsa lainnya. Ciri khas bangsa ini dapat dimanfaatkan dan dioptimalkan sebagai potensi keunggulan dan dikembangkan pada bidang pariwisata. Namun ditengah keuntungan alam yang dimiliki oleh Bangsa Indonesia, kenyataannya masih mengalami keterpurukan dan berbagai permasalahan yang sedang melanda. Permasalahan yang sangat sulit untuk dituntaskan saat ini seperti masalah kemiskinan dan belum meratanya pendapatan.

Pariwisata di Indonesia berkembang sangat pesat karena dapat menjamin kemajuan suatu daerah dalam konteks otonomi daerah utamanya meningkatkan kesejahteraan masyarakat (Utama, 2017). Selain itu, Bidang pariwisata adalah kunci utama dalam menghasilkan devisa negara dan membuka peluang investasi yang sebesar besarnya. Hal ini karena banyaknya wisatawan asing yang berkunjung ke Negara Indonesia. Era saat ini sektor pariwisata jelas dapat dijadikan sebagai industri dengan skala besar sehingga dapat menjadi alternatif dari melemahnya sektor industri minyak dan batu bara.

Kabupaten Trenggalek adalah salah satu Kabupaten di Indonesia yang memiliki potensi besar pada sektor pariwisata. Berdasarkan data yang dihimpun dari Dinas Pariwisata Kabupaten Trenggalek, Jumlah PAD ke Kabupaten Trenggalek sektor pariwisata pada Desember 2015 mencapai Rp. 5.915,720,900 naik 109 persen bila dibandingkan jumlah PAD Desember 2014 yang hanya tercatat sebanyak Rp. 5,424,477,200. Sementara itu, kenaikan PAD tahun 2014 sampai 2015 sebesar 109 persen terjadi penurunan PAD pada tahun 2016 menjadi Rp. 1,784,384,250 namun 3 (tiga) tahun selanjutnya PAD tersebut terus mengalami peningkatan.

Tabel 1. PAD Kabupaten Trenggalek dari pariwisata dalam 5 tahun terakhir

\begin{tabular}{|c|c|}
\hline Tahun & Jumlah PAD (Juta Rupiah) \\
\hline 2014 & $5.424 .477,200$ \\
\hline 2015 & $5,915.720,900$ \\
\hline 2016 & $1,784,384,250$ \\
\hline 2017 & $7,065,619,750$ \\
\hline 2018 & $7.312,820,500$ \\
\hline
\end{tabular}

Sumber: (BPS Kabupaten Trenggalek, 2020)

Berdasarkan Tabel diatas terlihat bahwa penerimaan PAD Kabupaten Trenggalek dari sektor pariwisata memiliki peningkatan setiap tahunnya namun mengalami penuruan drastis di tahun 2016. Hal ini dikarenakan terjadi perubahan mendasar dalam metode dan cara hitungnya. Selain itu di tahun 2016 masih belum 
memiliki metode baku dalam perhitungan PAD. Kondisi ini juga dialami oleh seluruh daerah di Provinsi Jawa Timur (BPS Kabupaten Trenggalek, 2020). Namun stelah tahun 2016, peningkatan jumlah PAD di Kabupaten Trenggalek selalu meningkat. Kondisi tersebut membuktikan bahwa pariwisata memiliki peran penting dalam meningkatkan perekonomian suatu daerah dan berkontribusi cukup besar dalam menambah pendapatan daerah. Pariwisata juga menjadi suatu sistem yang multikompleks dengan berbagai aspek yang saling terkait dan saling mempengaruhi antar sesama, serta menjadi sumber penggerak dinamika masyarakat yaitu dalam perubahan sosial, ekonomi, dan budaya.

Dewasa ini masyarakat banyak menggemari wisata yang menyajikan keindahan alamnya saja, namun juga menggemari interaksi dengan warga lokal dan keunggulan kulinernya. Saat ini telah banyak berkembang jenis wisata alternatif khususnya Desa Wisata di Kabupaten Trenggalek. Telah dijelaskan pada bagian sebelumnya bahwa desa wisata merupakan salah satu bentuk dari pariwisata berbasis masyarakat. Berkembangnya jenis wisata khusunya desa wisata ini membantu kehidupan sosial ekonomi serta budaya masyarakat sekitar, karena banyak melibatkan masyarakat lokal dalam pengembangannya. Agar suatu desa dapat dikatakan sebagai desa wisata maka perlu memiliki beberapa kriteria diantaranya memiliki potensi keunikan dan daya tarik wisata berupa alam pedesaan yang masih alami serta kehidupan sosial budaya masyarakat yang khas dan tetap dilestarikan. Pengembangan desa wisata dan masyarakat di dalamnya sebagai obyek daya tarik wisata pedesaan dapat dikembangkan melalui kegiatan pendampingan, penyuluhan dan pembinaan oleh dinas pariwisata. Selain mengoptimalkan wisata alam pantai seperti Pantai Prigi, Karanggongso, Damas, Pemerintah Kabupaten Trenggalek juga mengembangkan potensi desa yang disajikan dalam bentuk desa wisata.

Tabel 2. Jumlah Kunjungan Wisata di Kab. Trenggalek Tahun 2014-2018

\begin{tabular}{|c|c|}
\hline Tahun & $\begin{array}{c}\text { Jumlah } \\
\text { KunjunganWisata }\end{array}$ \\
\hline 2014 & 531,478 \\
\hline 2015 & 584,414 \\
\hline 2016 & 596,847 \\
\hline 2017 & 677,178 \\
\hline 2018 & 831,478 \\
\hline
\end{tabular}

Sumber: (BPS Kabupaten Trenggalek, 2020)

Berdasarkan data tentang jumlah kunjungan wisatawan mancanegara dan domestik di wilayah Kabupaten Trenggalek, dapat diketahui bahwa pada tahun 20142018 terjadi peningkatan jumlah kunjungan wisatawan yang cukup signifikan. Peningkatan jumlah kunjungan wisatawan dapat menambah Pendapatan Asli Daerah 
Kabupaten Trenggalek. Keberadaan desa wisata diharapkan mampu meningkatkan perekonomian masyarakat di sekitarnya dengan melalui penggalian potensi desa yang beranekaragam dan dapat dijadikan sebagai mata pencaharian kunci penduduk sekitar. Potensi desa yang dapat dikembangkan antara lain, potensi budaya, kuliner, kerajinan tangan dan keindahan alam. Terbentuknya desa wisata di Kabupaten Trenggalek selain merupakan kebijakan dan upaya yang dilakukan oleh pemerintah setempat, juga merupakan bentuk inisiatif dari masyarakat lokal yang mampu melihat kondisi dan potensi yang dimiliki oleh derahnya.

Salah satu desa wisata yang terdapat di Kabupaten Trenggaek bernama Desa Wisata Duren Sari yang beralamat di Dusun Singgahan, Desa Duren Sari Kecamatan Watulimo Kabupaten Trenggalek, Jawa Timur. Dikatakan sebagai desa wisata karena potensi alam di dalam desa tersebut melimpah dan masih terjaga hingga sekarang. Selain itu, kebudayaan juga masih dilestarikan di Desa Wisata yang terdiri dari kerawitan dan gamelan campursari. Namun realitas di lapangan Desa Wisata Duren Sari terkendala pada fasilitas yang kurang memadai, organisasi serta kelembagaan yang belum berjalan optimal, kurangnya modal dan anggaran, serta promosi dan pemasaran yang belum dioptimalkan dengan baik.

Pengembangan desa wisata tentunya akan melibatkan banyak stakeholder terkait, baik dalam bentuk kepengurusan dan ketenagakerjaan tempat wisata sampai pada kemandirian masyarakat untuk memanfaatkan peluang yang muncul dari akibat adanya desa wisata. Berdasarkan latar belakang yang sudah dijelaskan sebelumnya, maka penulis akan meneliti tentang "Model Quadruple helix dalam Pemberdayaan Perekonomian Lokal Berbasis Agrowisata di Desa Duren Sari Kabupaten Trenggalek". Adapun dalam penelitian ini bertujuan untuk mengetahui implementasi quadruple helix dalam pemberdayaan perekonomian lokal berbasis agrowisata di Desa Duren Sari Kabupaten Trenggalek. Selain itu, penelitian ini juga bertujuan untuk menemukan model interaksi setiap aktor helix dalam pemberdayaan perekonomian lokal berbasis agrowisata di Desa Duren Sari Kabupaten Trenggalek.

\section{TINJAUAN PUSATAKA}

\section{Model Quadruple Helix}

Perlu di ketahui bersama bahwa mengembangkan industri pariwisata di desa tidaklah mudah. Sulitnya masyarakat di desa dalam mengembangkan inovasi menjadi faktor penghambat dalam upaya pengembangan pariwisata berbasis potensi desa. Namun kondisi tersebut bukan tidak mungkin dilakukan apabila terjadi kolaborasi aktor dalam pelaksanaannya. Diperlukan adanya inovasi dan kolaborasi untuk menjawab persoalan serta menemukan peluang yang dapat dimanfaatkan oleh warga Desa Duren Sari Kabupaten Tulungagung dalam mengembangkan potensi desa yang dimiliki. 
Kolobarasi tersebut di sebut dengan model quadruple helix yaitu memadukan ide dan gagasan masing-masing stakeholder dalam merumuskan, mengimplementasikan, hingga mengevaluasi kegiatan inovatif guna mendongkrak perekonomian desa melalui sector wisata (Imron, 2020). Dalam kolaborasi tersebut, masing-masing stakeholder memiliki peran sesuai dengan keahlian dibidangnya. Adapun aktor/ stakeholder yang tergabung dalam model quadruple helix diantaranya pemerintah (government), pelaku usaha kreatif (business), akademsi (intellectual academia), dan Masyarakat (civil society).

Sejarah perkembangan model inovasi dalam meningkatkan perekonomian tidak terlepas dari kebutuhan manusia untuk terus meningkatkan kesejahteraan. Sehingga model-model inovasi yang telah dikonsepkan mengalami perkembangan terus menerus. Model quadruple helix lebih baik apabila di bandingkan dengan triple helix sebab teori tersebut lebih menekankan pada keberlangsungan kerjasama sosial yang berlandaskan aktivtas ekonomi normal. Fokus dari model quadruple helix yaitu proses inovasi non-linier yang saling berinteraksi dalam jaringan inovasi multi aktor (Leydesdorff, 2012)

Adanya model quadruple helix dalam pemberdayaan ekonomi lokal dapat memfasilitasi hubungan yang saling melengkapi antara akademisi, pemerintah, industri, dan masyarakat yang didefinisikan dalam 3 (tiga) hal yaitu (1) memfasilitasi kerjasama antara universitas/ akademisi dan bisnis untuk kepuasan yang lebih baik sesuai kebutuhan bersama dan kontribusi yang lebih besar untuk mendukung pemerintah menguatkan ekonomi nasional; (2) mengembangkan lingkungan yang sesuai untuk pengembangan kewirausahaan akademik, penggunaan pengetahuan, inovasi dan prestasi di semua bidang ilmu pengetahuan, penelitian dan aplikasi pengetahuan; (3) Mendorong dan menerapkan pengalaman praktek yang baik dalam bentuk kerjasama yang serasi antara lembaga pengetahuan, struktur ekonomi, lembaga negara dan masyarakat (Ješić \& Pejanović, 2019).

Lebih lanjut, konsep pemberdayaan ekonomi di bidang pariwisata perlu mengembangkan model quadruple helix sebab model tersebut menekankan pada sifat yang dinamis dalam proses inovasi. Sistem inovasi bekerja dengan baik pada model quadruple helix yang mengikutsertakan akademisi dalam mendukung kinerja pemerintah. Setiap stakeholder yang terlibat dalam sistem inovasi ini memiliki maksud dan tujuan yang berbeda tetapi memiliki aktivitas ekonomi yang sama mengarah pada pengembangan pariwisata lokal. Aktivitas ekonomi yang terjadi akan terus berkembang sebagai sistem inovasi yang baik, oleh sebab itu stakeholder yang terlibat perlu merencanakan model quadruple helix di dalam setiap industri pariwisata berbasi ekonomi lokal baik skala kecil, menengah, atau besar (Björk, 2014).

Sebagai aktor utama penggerak lahirnya inovasi, kreativitas, ide, ilmu pengetahuan dan teknologi yang sangat penting untuk pertumbuhan dan pengembangan industri kreatif, sistem Quadruple Helix menjadi payung yang 
menghubungkan antara A (Academician), B (Businessman), C (Civil Society) dan G (Government). Hubungan simbiosis mutualisme antara keempat aktor tersebut akan menentukan strategi pengembangan ekonomi kreatif yang kokoh dan berkelanjutan (Campbell et al., 2015). Pendekatan Quadruple Helix merupakan kelanjutan dari sistem Triple Helix yang meliputi A (Academician), B (Businessman), dan G (Government) yang pertama kali digagas oleh Etzkowitz. Etzkowitz (2017) berpendapat bahwa model Triple Helix (TH) sangat tepat untuk meningkatkan inovasi. Sedangkan dalam model Quadruple Helix ditambahkan Civil society yang berperan mengintegrasikan media, budaya dan konsumen (Mindarti \& Muzaqi, 2018).

Di bidang studi inovasi, model triple helix universitas, industri dan pemerintah telah digunakan untuk mempelajari kolaborasi berbagai pihak dalam desain pemberdayaan ekonomi masyarakat. Namun (Carayannis \& Campbell, 2010) membantahnya dan menyatakan bahwa Ekonomi berbasis pengetahuan memiliki proses inovasi harus juga menjelaskan budaya dan nilai-nilai publik, dan karenanya mereka mengusulkan model quadruple helix Gambar 1 menunjukkan model quadruple helix yang membedakan antara 1) negara / pemerintah, 2) industri / bisnis, 3) akademisi / universitas, dan 4) masyarakat umum / sipil berbasis media dan budaya. Semua ini harus dilibatkan dalam pemberdayaan ekonomi masyarakat (van Waart et al., 2016). Kolaborasi ini menjadi tantangan dan sejak saat itu semua pihak memiliki kepentingan yang berbeda, dan mungkin berpotensi menimbulkan konflik satu sama lain.

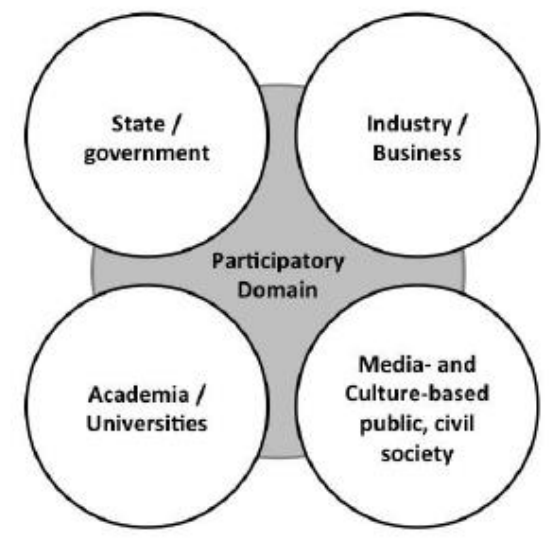

\section{Gambar 1. Model Quadruple Helix}

Sumber: (van Waart et al., 2016) 


\section{METODE PENELITIAN}

\section{Jenis Penelitian}

Jenis penelitian ini bersifat kualitatif yang merupakan penelitian yang berusaha untuk menuturkan pemecahan masalah yang ada sekarang berdasarkan kenyataan sosial dengan menggunakan data-data. Penelitian kualitatif sebagai prosedur penelitian yang menghasilkan data deskriptif berupa kata-kata tertulis atau lisan dari orangorang dan perilaku yang dapat diamati (Sugiono, 2016). Penelitian kualitatif didasarkan pada upaya membangun pandangan mereka yang diteliti secara rinci, dibentuk dengan kata-kata dan bukan data yang terbatas pada angka-angka. Penggunaan desain penelitian deskriptif dalam penelitian ini dimaksudkan untuk menjelaskan secara mendalam pelaksanaan pemberdayaan ekonomi masyarakat melalui pengembangan model quadruple helix di Desa Wisata Duren Sari di Desa Duren Sari berbasis agrowisata.

\section{Fokus Penelitian}

Fokus penelitian ini yang pertama mendiskripsikan dan menganalisis implementasi quadruple helix dalam pemberdayaan perekonomian lokal yang melibatkan 4 (empat) stakeholder: 1) peran pemerintah, 2) peran intelektual akademisi, 3) peran masyarakat, 4) peran sektor bisnis (industri kreatif). Sedangkan fokus penelitian yang kedua menemukan model interaksi anter helix dalam pemberdayaan ekonomi masyarakat desa wisata Duren Sari di Desa Duren Sari Kecamatan Watulimo Kabupaten Trenggalek. Kedua fokus penelitian tersebut dianggap sudah mampu menjawab masalah penelitian yang akan dilaksanakan.

\section{Teknik Analisis Data}

Analisis data adalah proses pencarian dan pengaturan secara sistematik hasil wawancara, catan-catatan, dan bahan-bahan yang dikumpulkan untuk meningkakan pemahaman terhadap semua hal yang dikumpulkan dan memungkinkan menyajikan apa yang ditemukan (Ibrahim, 2015). Sesuai dengan penelitian ini, maka teknik analisis data yang digunakan adalah teknik analisis data model interaktif. Teknik analisis data interaktif di perkenalakan oleh yang diawali dari pengumpulan data (data collection), Kondensasi data (data condensation), Penyajian data (data display), dan diakhiri dengan kesimpulan (conclusion) (Saldana, 2014).

\section{HASILPENELITIAN}

\section{Potensi Wisata Desa Duren Sari}

Desa wisata Duren Sari Kabupaten Trenggalek teretak di posisi 8¹6’09" Lintang Selatan dan 111 $41^{\prime} 05$ Bujur Timur. Secara administratif Desa Wisata Duren Sari 
terletak pada Kecamatan Watulimo, Kabupaten Trenggalek Provinsi Jawa Timur. Adapun secara luas lahan desa wisata ini tercatat seluas 506.662 Ha yang berbatasan wilayah dengan Desa Slewe Watulimo (utara), Desa Karanggandu (Selatan), Desa Margomulyo (Timur), dan Desa Bendoroto (Barat). Sebagian besar Desa Wisata Duren Sari adalah wilayah dataran rendah atau sekitar 388.487 Ha yang pada saat ini diisi oleh wilayah permukiman dan area bercocok tanam. Sedangkan 218.075 Ha sisanya merupakan wilayah dengan dataran tinggi dan perbukitan yang asri. Ketinggian pada Desa Wisata Duren Sari berkisar 25 sampai 750 mdpl serta beriklim tropis dengan rata-rata suhu antara $25^{\circ} \mathrm{C}$ sampai $30^{\circ} \mathrm{C}$. Adapun secara rinci berdasarkan kegunaan lahan Desa Wisata Duren Sari memiliki beberapa fungsi diantaranya pertanian dengan luas lahan $82 \mathrm{Ha}$, Pemukiman 209.572 Ha, dan 203.090 Ha sisanya adalah wilayah hutan negara. Wilayah Desa Wisata Duren Sari terbagi kedalam 4 (empat) dusun, 6 (enam) RW, dan 17 (tujuh belas) RT dengan jumlah penduduk di desa ini mencapai 5.616 jiwa yang terbagi dalam 2.831 jiwa penduduk perempuan, dan 2.785 jiwa penduduk laki-laki.

Berdasarkan hasil penelitian dilapangan yang dilakukan oleh peneliti baik wawancara maupun observasi langsung pengelola wisata di Desa Duren Sari dapat dikatakan sangat siap dan berpotensi menjadi kawasan wisata dengan level Jawa Timur. Kondisi tersebut terlihat ketika wisatawan yang berkunjung ke desa wisata akan mendapatkan sambutan hangat berupa welcome drink dengan suguhan minuman asli Kabupaten Trenggalek yaitu Wedang Jeser. Penyajianya pun sangat khas yaitu disajikan pada teko atau cangkir yang dibuat dari bahan bambu serta disuguhkan dengan pemandangan area sawah yang hijau dan asri. Teko dan cangkir pun buatan asli masayarakat sekitar Desa Wisata Duren Sari.

Sementara itu, paket wisata alam yang paling popular adalah jelajah "alas duren" atau IDF (International Durio Foresty). Secara singkat paket wisata ini bertemakan jelajah hutan durian terluas di kawasan Asia Tenggara. Claim atas hutan terluas di Asia Tenggara ini telah diresmikan oleh Menteri Pertanian pada tanggal 13 Bulan Mei Tahun 2016. Selain menjelajah para wisatawan akan dikenalkan dengan pohon durian yang berusia lebih dari seratus tahun, serta wisatawan akan diajak berkeliling merasakan kesegaran sungai di sekitar Duren Sari yaitu "Kali Bawok". Kali Bawok sendiri merupakan sungai yang luas dan mengalir di tengah-tengah perkebunan durian IDF. Selain itu, sungai ini memiliki cerita legenda yaitu ketika membasuh muka di sungai ini dipercaya akan memunculkan aura yang segar dan selalu awet muda. Terdapat pula hal yang unik di sekitaran alas duren yaitu tumbuhnya pohon kelapa muda di pesisir sungai kali bawok. Tentunya hal tersebut dapat bermanfaat bagi wisatawan untuk sejenak melepas dahaga.

Adapun paket wisata lainnya yang bisa ditawarkan oleh Desa Wisata Duren Sari adalah river tubing. Wahana ini berlokasi pada sungai kali Watulawang dan wisatawan baik asing maupun mancanegara dapat menikmati wisata yang memacu 
adrenalin ini dengan perlengkapan yang sesuai standart. Wahan ini dilengkapi dengan alat kelengkapan seperti helm, pelampung, deker tangan dan kaki. Selain itu fasilitas keamanan lainnya seperti tour guide yang sudah dilatih dengan professional. Perjalanan susur sungai yang dilalui sepanjang 700 meter cukup untuk memuaskan wisatawan dan mengacu adrenalin para wisatawan. Sementara itu, dilokasi akhir susur sungai disedikan ojek yang langsung membawa wisatawan menuju lokasi awal. Ojek yang disediakan merupakan swadaya dari pokdarwis dan menjadi bagian dari paket wisata.

Keberadaan sungai yang mengalir disepanjang desa juga memudahkan akses air bersih bagi warga untuk mengolah tanaman perkebunannya namun dalam konteks perekonomian masih menimbulkan beberapa kendala. Kendala yang pertama adalah ekonomi pendapatan bagi petani masih belum optimal yang disebabkan banyaknya lahan tidak dikelola dengan baik. Kendala kedua yaitu kesediaan sarana prasarana seperti akses jalan yang belum besar serta sungai yang belum dikelola oleh warga secara baik untuk mendapatkan kebermanfaatannya. Oleh sebab itu, saat ini warga dan perangkat desa berusaha terus membersihkan daerah sekitaran sungai dan fasilitas penunjang lainnya agar tidak merusak estetika salah satu tempat wisata di Kabupaten Trenggalek ini.

Dua kendala tersebut mulai mendapatkan alternatif solusi setelah terciptanya keinginan untuk menjalin kerjasama dengan beberapa stakeholder yang diawali oleh kerjasama dengan universitas seperti Universitas Islam Negeri Sunan Ampel Surabaya dan Universitas Brawiajaya Malang. Kedua kampus di Jawa Timur tersebut membuat kegiatan seperti Forum Group Discussion (FGD) dengan aparatur desa bagaimana mengelola anggaran bantuan dana desa dengan optimal dan mengembangan desa wisata setempat. Selain itu, kedua kampus tersebut menjadikan Desa Wisata Duren Sari sebagai pusat penelitian dan planning project pembangunan ekonomi masyarkat yang dimulai dari desa.

Diawali pada tahun 2016 Pemerintah Kabupaten Trenggalek terus mengembangkan Desa ini menjadi Desa Wisata yang mampu memberi kontribusi terhadap pendapatan daerah Kabupaten Trenggalek. Sementara itu upaya dari Pemerintah Kabupaten Trenggalek di dukung oleh pemerintah pusat sejak tahun 2019 melalui Kementerian Desa Pembangunan Daerah Tertinggal dan Transmigrasi. Dukungan tersebut berupa program PIID-PEL atau pilot inkubasi inovasi desa pengembangan ekonomi lokal yang disahkan oleh Kemendes pada surat nomor 115/PMD.01.05/VII/2019. Program PIID-PEL ini adalah wujud dari upaya pemerintah pusat secara konkrit untuk mewujudkan misi pemberdayaan ekonomi lokal yang tertuang dalam RPJMN periode 2015-2019. Dalam dokumen RPJMN 2015-2019 ditargetkan adanya pengurangan jumlah desa tertinggal sejumlah 5.000 desa dan segera menambah jumlah desa dengan kategori desa mandiri sebesar 2.000 desa. Dengan adanya program tersebut Kemendes memiliki tujuan mendorong 
produktivitas dan kemajuan ekonomi lokal desa secara progresif serta dalam implementasinya melibatkan kelompok usaha desa, BUMDES, pemerintah, masyarakat lokal, akademisi, dan pelaku bisnis professional. Kolaborasi dan kerjasama dilakukan secara menyulur dan berkelanjutan dalam rangka meningkatkan kesejahteraan ekonomi masyarakat desa. Implikasi dari program ini yaitu meningkatnya omzet usaha, terbukanya lapangan kerja, meningkatnya PAD, dan memunculkan produk unggulan desa.

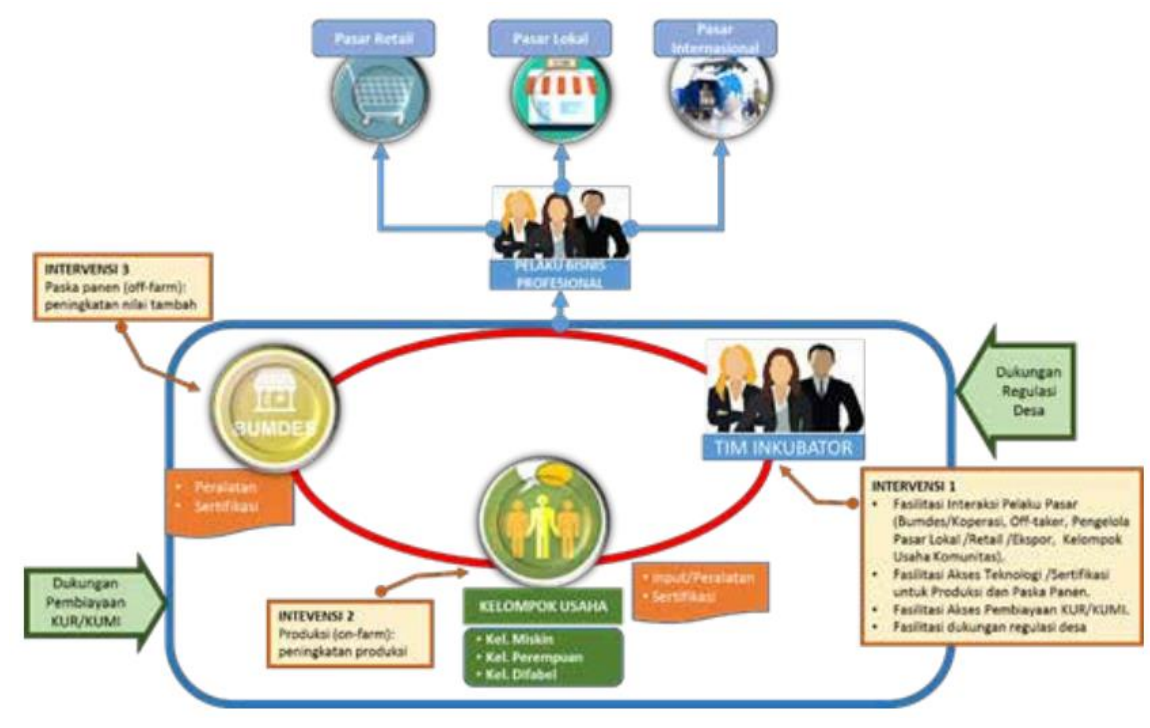

Gambar 2. Kerangka Konsep PIID-PEL

Sumber : Kemendes, 2019

\section{Implementasi Quadruple Helix dalam Pemberdayaan Perekonomian Lokal}

Desa Wisata Duren Sari merupakan salah satu desa wisata yang terbentuk dari pemberdayaan masyarakatnya dan kesadaran masyarakatnya sendiri. Kesadaran masyarakat akan potensi desa mereka yang asri dan memiliki banyak lahan yang dapat di manfaatkan untuk di jadikan tempat wisata. Hal ini di mulai sejak tahun 2016 dan terus diupayakan hingga saat ini. Awalnya semua mata pencaharian masyarakat Desa Duren Sari sebagian besar merupakan petani. Namun, masyarakat mulai khawatir karena kebutuhan yang semakin meningkat dan hasil pertanian yang belum tentu, mereka mulai merasa membutuhkan tambahan penghasilan. Kemudian mereka mulai musyawarah untuk mencari ide agar permasalahan mereka dapat berkurang. Dari hasil musyawarah tersebut mereka mulai menyadari akan potensi desa mereka sendiri terlebih dalam hal wisata, mengingat banyak tempat yang 
menarik akan tetapi tidak dikelola dengan baik sehingga hanya terbengkalai saja, seperti pemandangan yang indah, desa yang masih memiliki udara yang sejuk jauh dari polusi seperti yang berada di perkotaan serta kebudayaan yang masih asli dan selalu dijaga kelestariannya. Hal itulah yang melatarbelakangi terbentuknya Desa Wisata Duren Sari.

Adapun untuk mewujudkan hal tersebut, mereka mulai membuat strategi yang dapat dilakukan untuk mewujudkan Desa Wisata. Strategi yang digunakan untuk memberdayaan ekonomi masyarakat Desa Wisata Duren Sari seperti pelatihan home industry, yaitu pelatihan tentang industri rumahan yang dapat dijalankan ibuibu sehingga mereka tidak menganggur dan produktif setiap harinya, Pelatihan homestay, pelatihan ini dimungkinkan akan sangat berguna melihat semakin hari semakin banyak wisatawan yang berkunjung untuk menikmati liburan di Desa Wisata Duren Sari, dan Pelatihan pemasaran pariwisata, pelatihan ini sangat berguna untu memasarkan pariwisata yang ada di Desa Wisata Duren Sari. Pelatihan tersebut dilaksanakan rutin di Desa untuk kemajuan Desa Wisata Duren Sari. Pelatihan diadakan oleh Dinas Pariwisata dan Kebudayaan Kabupaten Trenggalek. Tidak hanya itu pelatihan juga ada yang diadakan dari dana iuran pribadi mereka sendiri. Sementara itu pelatihan dari Pemerintah Kabupaten Trenggalek, diadakan 2 kali setahun dan pelatihan yang berasal dari dana pribadi itu diadakan 2 kali setahun juga. Bukan hanya masyarakatnya saja yang melakukan, akan tetapi ada pula pelatihan untuk anggota Pokdarwis. Pelatihan tersebut tentang manajemen pengelolaan wisata. Manfaat dari diadakannya pelatihan tersebut sangat dirasakan oleh masyarakat Desa Wisata Duren Sari.

Sementara itu, upaya terakhir adalah dengan melakukan kerjasama. Kerjasama sangat diperlukan untuk meningkatkan dan mengembangkan Desa Wisata Duren Sari. Untuk mewujudkan hal tersebut maka, dibentuklah Kelompok Sadar Wisata atau biasa disebut Pokdarwis. Pokdarwis merupakan salah satu bentuk pemberdayaan masyarakat. Pokdarwis bertugas untuk mensosialisasikan kepada masyarakat konsep Desa Wisata Duren Sari sebagai desa wisata mulai dari Potensi Alam, Kesenian Tradisional, Home Industri, Home Stay. Salain itu Pokdarwis juga berfungsi untuk menampung kritik, saran, dan ide yang dimiliki masyarakat Desa. Dengan adanya Pokdarwis lambat laun masyarakat Desa Sawahan mulai menyadari potensi yang ada di desa mereka yang kemudian mereka saling bahu membahu dan selalu ikut berpartisipasi setiap ada kegiatan untuk memajukan desa mereka.

Seperti pada konteks penelitian yang dilakukan, pola dan model kolaborasi quadruple helix pastinya lebih relevan apabila disbanding dengan konsep triple helix. Hal tersebut dikarenakan stakeholder yang berperan dan menjalankan fungsinya lebih dari 3 (tiga) aktor. Ke-empat aktor yang berperan dalam pola kolaborasi ini adalah pemerintah, bisnis/industri, intelektual akademis, dan aktor keempat adalah organisasi non-profit atau biasa disebut dengan lembaga swadaya masyarakat (LSM) 
(Lindberg et al., 2014). Bahkan dalam kolaborasi quadruple helix ini dinyatakan bahwa munculnya inovasi disebabkan dari kebutuhan pengguna langsung (user-driven innovation) sebagai pengguna yang selanjutnya diformulasikan sebagai helix keempat (Yun \& Liu, 2019).

Quadruple Helix juga diklasifikasikan kedalam 2 (dua) hal utama yaitu budaya dan media, serta keikutsertaan masyarakat lokal dalam strategi memproduksi ilmu pengetahuan dan inovasi (Mindarti \& Muzaqi, 2018). Model Quadruple Helix ini mengharuskan partisipasi masyarakat lokal secara lebih ingklusif (Muzaqi et al., 2019). Partisipasi masyarakat dinilai penting oleh karena menjadi sumber inovasi dan kreativitas. Sebagai sebuah model kolaborasi quadruple helix adalah pengembangan dari konsep triple helix karena telah mengintegrasikan dengan civil society serta terintegrasi dengan ilmu pengetahuan dan inovasi dalam menjalankan usaha (Campbell et al., 2015). Quadruple Helix adalah pola interaksi secara terpadu antara government, business, academia, dan civil society. Model ini terbukti bahwa kreatif dan inovasi dapat mendukung keberhasilan untuk mencpai tujuan bersama. Kolaborasi yang terjalin dalam model quadruple helix memiliki tugas dan fungsi memajukan pengembangan dan ilmu teknologi yang dimilikinya. Ke-empat helix dapat berkerjasama dan berinteraksi dalam membentuk suatu keadaan yang inovatif (Nordberg, 2017).

Seluruh aktor dan stakeholder yang terlibat (pemerintah, swasta, intelektual, dan warga lokal) secara efektif dan efisien saling berinteraksi dan saling bertukar pikiran melalui forum diskusi kecil (Carayannis et al., 2019). Masing-masing aktor dan stakeholder dapat berperan sesuai kapabilitas dan kompetensinya. Government sector memiliki fungsi memformulasikan kebijakan, regulasi dan dukungan berupa modal. Private sector dan intelektual akademisi memiliki sebagai lembaga penyedia (provider) serta mendorong ilmu pengetahuan dan teknologi inovasi. Sementara itu, helix keempat yaitu masyarakat sipil memiliki peran yang juga strategis. Masyarakat bukan hanya sebagai user namun juga berperan serta dalam menemukan gagasan konkrit yang memang lebih mengerti kondisi eksisting di wilayahnya. Gagasan tersebut muncul dari segala sumber. Analisis di bawah ini akan lebih membahas peran dari setiap stakeholder yang ada dalam kolaborasi quadruple helix dan hasil dari kajian ini menjadi latar belakang empris di Desa Duren Sari Kabupaten Trenggalek.

\section{Peran Sektor Pemerintah}

Setelah mendapatkan payung hukum dari kebijakan program PIID-PEL (pilot inkubasi inovasi desa pengembangan ekonomi lokal), pemerintah pusat melalui Kementerian Pemberdayaan Desa Daerah Tertinggal dan Transmigrasi (helix pertama) menjadi aktor utama dalam proses kolaborasi ini. Pemerintah pusat didukung oleh Pemerintah Kabupaten Trenggalek bertindak sigap dan cepat dalam menjalankan 
program unggulan bagi pengembangan ekonomi lokal ini. Selain itu, lokasi wisata yang berada di tanah milik desa, maka pemerintah desa segera memformulasikan kebijakan yang sangat fundamental berupa pemanfaatan lahan tersebut menjadi lokasi yang secara legal formal menjadi Desa Wisata Duren Sari. Selain itu, pemerintah daerah juga terus melaksanakan promosi dan pelatihan warga sekitar guna menambah cabang usaha baru di Desa Duren Sari.

\section{Peran Sektor Intelektual Akademisi}

Interaksi yang terjalin antar stakeholder menjadi sangat strategis untuk dilakukan disaat inovasi berbasis desa wisata menjadi tujuan utama. Sebab kegiatan ini bukan hanya mengembangkan fisik semata namun juga menumbuhkembangkan kualitas Sumber Daya Manusia (SDM) bagi lokasi sekitar. Oleh sebab itu, peran intelektual yang dilakukan oleh Universitas di Jawa Timur sangat penting untuk diimplementasikan. Dengan keterlibatan universitas akan menambah pemanfaatan dari sisi inovasi dan teknologi. Penguatan kapasitas (softskill) telah banyak dilakukan oleh Universitas Brawijaya dan Universitas Sunan Ampel Surabaya sebagai fungsi helix kedua (intelektual akademisi) dan diharuskan menyajikan pengetahuan yang lebih aplikatif pada para user.

Beberapa aktivitas yang dilakukan oleh intelektual akademisi antaranya memfasilitasi kegiatan semcam pelatihan dan pemasaran. Selain itu pelatihan lebih difokuskan kepada edukasi konsep desa wisata, budidaya buah durian, serta pelatihan kerajinan dan budidaya buah durian. Disamping itu, akademisi juga melakukan fasilitasi kerjasam dengan berbagai pelaku usaha dan dilakukan dengan tujuan keberlangsungan desa wisata ini.

Seperti yang tertuang dalam pedoman PIID-PEL 2019 yang dimaksud dengan "ingkubator" dalam implementasi program ini adalah sebuah lembaga melakukan kegiatan yang didisain untuk pembinaan dan progresifitas kelangsungan sebuah pembangunan ekonomi lokal. Pembinaan dan pengembangan yang dilakukan melalui rangkaian kegiatan peningkatan kapasitas untuk menciptakan usaha lebih untung atau profitable. Berdasarkan konsep diatas incubator bisnis yang diciptakan oleh beberapa universitas telah ikut serta dalam mendisain konsep Desa Wisata dari hulu hingga hilir.

\section{Peran Sektor Bisnis (Pelaku Usaha Kreatif)}

Sehubungan dengan konsep desa wisata menjadi tujuan akhir dari kolaborasi ini, maka peran serta multi aktor menjadi sangat penting dan krusial. Meperluas jejaring kerjasama dengan pihak luar menjadi suatu aktivitas inti dalam proses ini. Pihak luar yang ditentukan pastinya harus dapat memberikan kontribusi pada goals atau tujuan yang sudah dirumuskan bersama. Pendekatan yang dilakukan oleh helix ke tiga ini menjadi pilihan bagi aktor yang sudah berkontribusi terhadap inovasi menjapai 
dalam tujuan bersama. Sektor Bisnis dalam konteks penelitian ini adalah Usaha Mikro Kecil Menengah (UMKM) yang ada di Kabupaten Trenggalek. Pelaku usaha dibidang transportasi, akomodasi, jasa paket wisata, dan kuliner mendukung pada pengembangan desa wisata Duren Sari. Adapun jasa paket wisata dan transportasi bertanggungjawab terhadap promosi dan pemasaran wisata Duren Sari. Sedangkan kuliner dan akomodasi juga diberi pelatihan untuk mengajarkan bagaimana menyambut wisatawan dengan ramah dan tentunya memberi kesan yang baik. Pelatihan juga dilakukan dengan maksud memberi kemampuan pelaku UMKM dalam mengolah buah durian menjadi sektor usaha baru dan juga pelatihan bagaimana mengolah bambu menjadi peralatan makan yang sangat berguna bagi usaha di bidang kuliner.

\section{Peran Sektor Masyarakat Lokal}

Konsep Desa Wisata sendiri tentunya tidak dapat terlepas dari keikutsertaan masyarakat lokal dalam tren pembangunan potensi ekonomi lokal. Namun hal utama yang harus menjadi perhatian adalah partisipasi aktif warga sekitar dalam memberi dukungan terhadap program program yang telah dijalankan. Berbicara tentang Desa Wisata Duren Sari masyarakat yang tergabung dalam berbagai kelompok yang diinisiasi oleh Lembaga Masyarakat Desa Hutan (LMDH), Kelompok Sadar Wisata (POKDARWIS), Karang Taruna, dan ibu-ibu PKK telah melakukan serangkaian kegiatan diluar program pemerintah daerah guna menciptkan atmosfer usaha yang lebih terintegrasi. Semua potensi yang dimiliki sudah dimunculkan, seperti LMDH melakukan pelatihan diadakan secara periodik oleh pemerintah desa bagi masyarakat. Pelatihan ini terdiri dari 2 pelatihan yaitu pelatihan home industry yang difokuskan pada Pembinaan dan pelatihan kuliner, kerajinan, dan meningkatkan kwantitas, kwalitas serta keragaman jenis produk home industry. Selanjutnya adalah adalah pelatihan pengelolaan homestay atau penginapan.Di Desa Wisata Duren Sari saat ini bermunculan homestay yang dikelola masyarakat. Beberapa rumah 'disulap' menjadi penginapan, tetapi juga ada bangunan baru yang memang dibangun khusus sebagai homestay untuk wisatawan. Tidak sedikit masyarakat yang menganggap bahwa pengelolaan homestay itu mudah. Akan tetapi dalam kenyataannya banyak diantara masyarakat yang kesulitan dalam mengelolanya. Sehingga dengan adanya pelatihan ini banyak masyarakat yang merasa terbantu.

\section{Model Interaksi antar Helix dalam Pemberdayaan Ekonomi Masyarakat Desa Wisata Duren Sari}

Setiap stakeholder yang terkait dengan kolobarasi quadruple helix memiliki tugas dan peran yang berbeda dilihat dari kapabilitas dan kompetensinya. Namun sebagai konsekuensi sebuah sistem atau pola, masing-masing aktor dalam helix harus berkerjasama dan berkolaborasi sebagai suatu kesatuan yang utuh dan solid. Sinergi 
aktor yang tercipta jika diperankan dengan optimal dapat berjalan dengan baik apabila tidak bergantung pada aktor lainnya (Sofhani \& Nurrahma, 2016). Gambar dibawah ini akan memperlihatkan bagaimana pola yang terjalin antar aktor dalam konsep Quadruple Helix pengembangan Desa Wisata Duren Sari di Kabupaten Trenggalek.

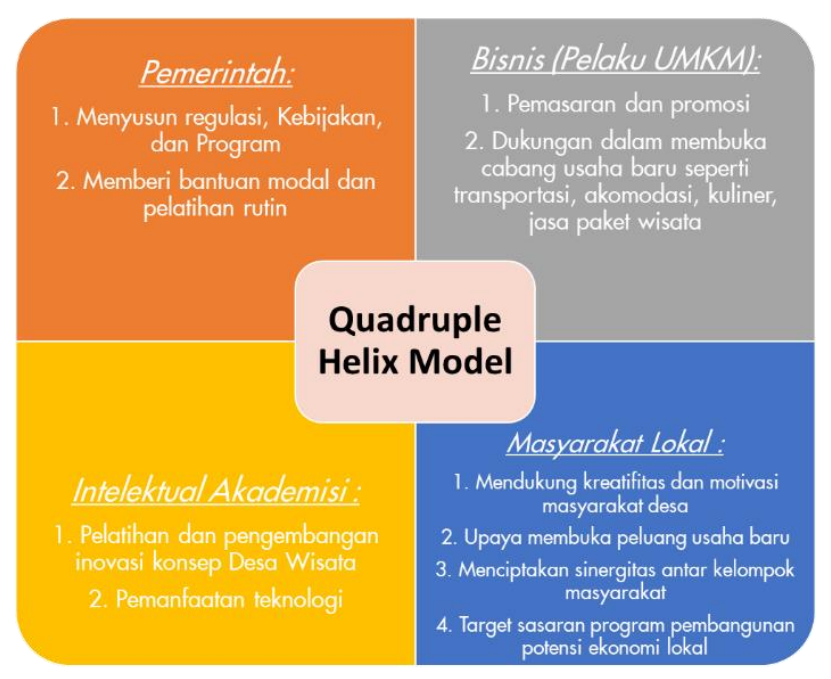

\section{Gambar 3. Model Quadruple Helix Pengembangan Desa Wisata Duren Sari Sumber : Peneliti, 2020}

Seperti yang telah tersaji pada gambar 3, riset ini menggambarkan bentuk interaksi antar helix dalam konteks pengembangan ekonomi lokal. Sebelum adanya dukungan dari pemerintah pusat berupa program PIID-PEL, ke-empat stakeholder ini telah bersama sama melakukan interaksi namun belum memiliki visi dan misi yang jelas. Masing-masing aktor menjalankan fungsi nya namun belum mengarah kepada tujuan bersama. Oleh sebab itu, dengan adanya pendekatan model pengembangan bisnis yang bernama Quadruple Helix diharapkan masing-masing aktor akan melaksanakan fungsi dan tujuan secara lebih terorganisir dan mengarah pada pencapaian misi bersama yaitu meningkatkan pendapatan daerah melalui pemanfaatan potensi ekonomi lokal yang ada di Desa Duren Sari Kecamatan Watulimo Kabupaten Trenggalek.

Terdapat 5 (lima) karakteristik pendekatan model Quadruple Helix dalam pengembangan potensi ekonomi lokal di Desa Duren Sari. Karakteristik ini merupakan implikasi dari etentitas nyata untuk menjaga ritme kolaborasi. Adapun ke-lima karakteristik ini antara lain pertama, setiap kegiatan yang itu tujuannya untuk pengembangan desa wisata tidak hanya diinisiasi oleh pemerintah saja, namun aktor akademisi, UMKM, dan kelompok masyarakat dapat memulai inisiasi. Kedua, 
keputusan publik tidak terpaku hanya pada aktor-aktor publik yang merumuskan namun juga dapat diintervensi oleh aktor eksternal. Ketiga, aktor yang terlibat di bermacam kegiatan seperti forum bukan hanya terdiri dari institusi publik saja sehingga ide-ide yang muncul terkadang muncul dari unsur manapun. Keempat, keputusan disetujui bersama sama dan bermuara pada consensus. Kelima, kerjasama antar aktor tersebut menitikberatkan pada alternatif keputusan yang paling ideal tanpa ada intervensi lebih dari kelompok yang berkepentingan sebab kaitanya adalah pencapaian tujuan bersama.

Berdasarkan lima karakteristik tersebut, berdampak pada kemunculan gagasan inovasi yang tanpa batas dan sangat mungkin dikembangkan untuk mewujudkan Desa Wisata Duren Sari Kabupaten Trenggalek. Inovasi ini tercipta dilatarbelakangi oleh permasalahan ekonomi dan kesejahteraan yang sedang dihadapi oleh masyarakat setempat. Keberadaan Desa Wisata Duren Sari, diharapkan kedepannya pemerataan ekonomi warga sekitar dapat terwujud dan tidak ada lagi permasalahan kesejahteraan di Kabupaten Trenggalek. Kondisi ini disebabkan masyarakat Desa Duren Sari akan memiliki banyak potensi dan peluang usaha yang lebih terbuka.

Tabel 3. Penciptaan Inovasi Baru Hasil dari Kolaborasi Quadruple Helix

\begin{tabular}{|l|l|l|}
\hline \multicolumn{1}{|c|}{ Bentuk Inovasi } & \multicolumn{1}{|c|}{ Bentuk Kegiatan } & \multicolumn{1}{c|}{$\begin{array}{c}\text { Target } \\
\text { Sasaran }\end{array}$} \\
\hline $\begin{array}{l}\text { Olahan baru dari } \\
\text { buah durian }\end{array}$ & $\begin{array}{l}\text { Memberikan pelatihan tata cara } \\
\text { pengolahan buah durian }\end{array}$ & $\begin{array}{l}\text { Ibu-Ibu PKK, } \\
\text { dan Ibu } \\
\text { rumah } \\
\text { tangga }\end{array}$ \\
\hline $\begin{array}{l}\text { Membuka paket } \\
\text { wisata alam yang } \\
\text { lebih bervariatif }\end{array}$ & $\begin{array}{l}\text { Perbaikan infrastruktur } \\
\text { penunjang seperti aksesibilitas } \\
\text { jalan, lahan parker yang lebih } \\
\text { luas, fasilitas umum, dll }\end{array}$ & $\begin{array}{l}\text { Pokdarwis, } \\
\text { LMDH, } \\
\text { Karang } \\
\text { Taruna }\end{array}$ \\
\hline $\begin{array}{l}\text { Membuka cabang } \\
\text { wirausaha baru }\end{array}$ & $\begin{array}{l}\text { Menetapkan produk } \\
\text { unggulan daerah } \\
\text { Menciptakan usaha kuliner } \\
\text { yang lebih otentik } \\
\text { Mengikuti pameran UMKM } \\
\text { dengan skala internasional }\end{array}$ & $\begin{array}{l}\text { Ibu-Ibu PKK, } \\
\text { Pokdarwis, } \\
\text { Karang } \\
\text { Taruna }\end{array}$ \\
\hline $\begin{array}{l}\text { Melahirkan duta } \\
\text { wisata Duren Sari }\end{array}$ & $\begin{array}{l}\text { Membentuk duta wisata } \\
\text { rutin setiap tahun } \\
\text { Menciptakan komunitas } \\
\text { muda kreatif }\end{array}$ & $\begin{array}{l}\text { Pemuda, } \\
\text { karangtaruna } \\
\text { potensial }\end{array}$ \\
\hline
\end{tabular}




\begin{tabular}{|l|l|l|}
\hline $\begin{array}{l}\text { Kerjasama kemitraan } \\
\text { dengan sektor swasta }\end{array}$ & $\begin{array}{l}\text { MOU kerjasama baik skala } \\
\text { mikro, kecil, menengah, atau } \\
\text { besar }\end{array}$ & $\begin{array}{l}\text { Pokdarwis, } \\
\text { LMDH, PKK, } \\
\text { Aparatur } \\
\text { desa }\end{array}$ \\
\hline
\end{tabular}

Sumber : Peneliti, 2020

Bentuk inovasi diatas tercipta atas adanya kolaborasi Quadruple Helix (pemerintah, intelektual akademisi, bisnis, dan masyarakat). Lima karakteristik yang lahir dengan adanya kolaborasi ini menciptakan konsep inovasi baru yang sangat berpeluang bagi semua pihak meskipun pada saat penerapannya perlu diadakan kajian ulang. Namun kuncinya adalah komitmen dan konsistensi setiap stakeholder yang akan mempercepat pembangunan ekonomi wilayah sekitar. Upaya memunculkan kreatifitas dan inovasi dapat muncul dari helix manapun supaya keunggulan wisata lokal dapat selalu terjaga ditengah munculnya destinasi baru yang lebih beragam. Kondisi ini karena setiap inovasi dan kreatifitas yang diciptakan akan sulit ditiru oleh pesaing dimanapun. Oleh sebab itu, kondisi pasar, konsumen, serta pemanfaatan scintec harus sekali dikembangkan dan di laksanakan secara komprehesif.

Apabila kolaborasi Quadruple Helix di Desa wisata Duren Sari Kabupaten Trenggalek dalam konteks pemeberdayaan masyarakat lokal diharapkan akan menjadi ingkubator bisnis yang didalamnya muncul berbagai macam inovasi dan interaksi antar helix. Kolaborasi Quadruple Helix membuktikan bahwa dapat menciptkan iklim usaha yang sangat produktif dan mengembangkan desa lebih terfokus pada konsep desa wisata. Ke-empat helix tersebut adalah faktor utama dalam memunculkan gagasan kreatif dan inovatif dalam pengembangan ilmu pengetahuan dan penerapan teknologi terbarukan bagi berkembangnya desa wisata.

\section{Simpulan}

\section{KESIMPULAN DAN SARAN}

Desa Wisata Duren Sari seyogyanya dapat menerapkan model Quadruple Helix yang mampu menciptakan kreatifitas dan inovasi sampai pengetahuan baru yang didukung oleh keseluruhan stakeholder helix (pemerintah, bisnis, intelektual akademisi, masyarakat). Adanya dukungan dari aktor helix ini dapat mendokrak perekonomian sebuah wilayah menjadi lebih berkembang dan terintegrasi. Hal ini dikerenakan adanya tujuan bersama dan dilaksanakan berdasarkan kapabilitas serta kapasitas masing-masing aktor. Warga lokal juga tidak hanya menjadi objek pembangunan semata namun berpartisipasi aktif menyumbangkan gagasannya dalam menciptakan kesejahteraan ekonomi yang lebih merata. Oleh sebab itu, sinergitas quadruple helix menjadi modal utama memunculkan kreatifitas dan inovasi. 


\section{Saran}

Riset ini juga merekomendasikan interaksi yang terjalin antar helix (pemerintah, intelektual, bisnis, dan masyarakat) dalam konteks memberdayakan perekonomian lokal bukan hanya dari sektor pariwisata namun juga UMKM, perdagangan, atau bahkan sektor pendidikan. Kolaborasi yang terjalin secara ideal, konsisten, saling berbagi ilmu pengetahuan, dan integratif akan lebih mempercepat tujuan bersama yaitu pemerataan ekonomi. Hal tersebut harus diperhatikan setiap aktor helix yang terlibat dengan tujuan minimnya terintervensi oleh kelompok kepentingan semata. Penelitian selanjutnya akan sangat penting dilakukan apabila konsep quadruple helix ini sudah ideal dijalankan karena dinamika yang dimunculkan oleh kolaborasi ini berpotensi menimbulkan konflik kepentingan beberapa golongan. Selain itu, mungkin saja terdapat aktor helix lainnya yang akan menjadi pendukung dan berperan penting dalam pencapaian tujuan bersama menciptakan pemberdayaan ekonomi daerah berbasis Desa Wisata.

\section{REFERENSI}

Björk, P. 2014. The DNA Of Tourism Service Innovation: A Quadruple Helix Approach. Journal of the Knowledge Economy, 5(1), 181-202.

BPS Kabupaten Trenggalek. 2020. Kabupaten Trenggalek Dalam Angka Tahun 2020. BPS Kabupaten Trenggalek.

Campbell, D. F. J., Carayannis, E. G., \& Rehman, S. S. 2015. Quadruple helix structures of quality of democracy in innovation systems: the USA, OECD countries, and EU member countries in global comparison. Journal of the Knowledge Economy, 6(3), 467-493.

Carayannis, E. G., \& Campbell, D. F. J. 2010. Triple Helix, Quadruple Helix and Quintuple Helix and how do knowledge, innovation and the environment relate to each other?: a proposed framework for a trans-disciplinary analysis of sustainable development and social ecology. International Journal of Social Ecology and Sustainable Development (IJSESD), 1(1), 41-69.

Carayannis, E. G., Grigoroudis, E., Stamati, D., \& Valvi, T. 2019. Social business model innovation: A quadruple/quintuple helix-based social innovation ecosystem. IEEE Transactions on Engineering Management.

Firmanto, F. 2019. Peranan Pajak Daerah dalam Meningkatkan Pendapatan Daerah Berdasarkan Undang-Undang Nomor 32 Tahun 2004 Tentang Pemerintahan Daerah. Jurnal Pahlawan, 2(1), 24-28.

Ibrahim, M. A. 2015. Metodologi penelitian kualitatif. Bandung: Alfabeta.

Imron, M. 2020. Kolaborasi Quadruple Helix dalam Menciptakan Inovasi Konsep Wisata Edukasi Kampung Nanas di Desa Palaan. JPSI (Journal of Public Sector Innovations), 4(2), 68-74. 
Ješić, J., \& Pejanović, R. 2019. Fostering rural tourism development-quadruple helix model approach. TISC-Tourism International Scientific Conference Vrnjačka Banja, 4(2), 118-135.

Leydesdorff, L. 2012. The triple helix, quadruple helix,..., and an N-tuple of helices: explanatory models for analyzing the knowledge-based economy? Journal of the Knowledge Economy, 3(1), 25-35.

Lindberg, M., Lindgren, M., \& Packendorff, J. 2014. Quadruple Helix as a way to bridge the gender gap in entrepreneurship: the case of an innovation system project in the Baltic Sea region. Journal of the Knowledge Economy, 5(1), 94-113.

Mindarti, L. I., \& Muzaqi, A. H. 2018. Micro, Small, And Medium Enterprises (MSMEs) Empowerment Through Quadruplehelix Approach (A Study At Department of Micro Enterprise Cooperatives and Trade in Batu City). Journal Ilmu Sosial, Politik, Dan Ilmu Pemerintahan, 7(2), 1-13.

Muzaqi, A. H., Pratama, M. R., \& Widodo, S. (2019). Strategi Peningkatan Kesejahteraan Sosial Penyandang Disabilitas Netra Melalui Kebijakan Ingklusif. Journal Publicuho, 3(3), 381-393.

Nordberg, K. 2017. Enabling regional growth in peripheral non-university regions: The impact of a quadruple helix intermediate organisation. In Revolutionizing Economic and Democratic Systems (pp. 185-217). Springer.

Saldana. 2014. Qualitative Data Analysis, A Methods Sourcebook. UI-Press.

Sofhani, T. F., \& Nurrahma, V. 2016. Pengembangan Wilayah Berbasis Quadruple Helix: Analisis Jaringan Antar Aktor Dalam Pengembangan Industri Kreatif Cimahi. Tidak Untuk Disalin.

Sugiono, S. 2016. Metode Penelitian Kuantitatif, Kualitatif, dan R \& D. Bandung: Alfabeta. Suman, A., Putra, R. E. N., Amalia, S. K., Hardanto, H., Kusuma, C. A., \& Amir, F. 2019. Ekonomi Lokal: Pemberdayaan dan Kolaborasi. Universitas Brawijaya Press.

Utama, I. G. B. R. 2017. Pemasaran Pariwisata. Penerbit Andi.

van Waart, P., Mulder, I., \& de Bont, C. 2016. A participatory approach for envisioning a smart city. Social Science Computer Review, 34(6), 708-723.

Yun, J. J., \& Liu, Z. 2019. Micro-and macro-dynamics of open innovation with a quadruplehelix model. Multidisciplinary Digital Publishing Institute. 